\title{
Pengaruh Rasio Ha/TCP terhadap Karakteristik Komposit BCP-Gelatin-CMC sebagai Bahan Injectable Bone Substitute
}

\author{
Mochammad Dachyar Effendi*, Nandang Suhendar \\ Pusat Teknologi Material-BPPT, Kawasan PUSPIPTEK, Serpong, 15314 \\ *Surel: dachyar.effendy@bppt.go.id
}

\section{INFO ARTIKEL}

Diterima 10 Januari 2019

Direvisi 12 November 2019

Disetujui 27 Desember 2019

Nomor Artikel 201909

Halaman 15-20

\section{Kata kunci:}

Injectable bone subtitute

Hydroxyapatite

Komposit keramik-

polimer

Kerusakan tulang

\section{Abstract}

Adding bone graft material into the bone cavity could be one of alternative to avoid bone fracture caused by osteoporosis. A major weakness of current orthopedic implant materials, for instance sintered hydroxyapatite (HA), is that they exist as a hardened form, requiring the surgeon to fit the surgical site around an implant to the desired shape. A convenient alternative to suspension bone filling materials are injectable bone substitutes (IBS). This study investigated material formula consist of bioceramic hydroxyapatite (HA) and tricalcium phosphate (TCP as filler, and polymer carboxymethyl cellulose $(C M C)$ and gelatin as matrix. Three groups were classified based on the ratio of HA/TCP in the solid phase (70:30;50:50; 40:60). FTIR analysis showed that absence of fungsional groups of $\mathrm{PO}_{4}{ }^{3-}$, carboxyl and $\mathrm{NH}_{2}$ related to composition components. An increase in porosity due to changes in morphology was confirmed by polarity microscope image. Tensile strength test showed compressive strength was decrease caused by increasing TCP concentration. All groups showed structurally similar to cancellous bone related to porosity and mechanical strength properties.

Keywords: injectable bone substitute, hydroxyapatite, ceramic-polymer composite, bone defect

\begin{abstract}
Abstrak
Penambahan bahan semen tulang kedalam rongga tulang dapat menjadi salah satu alternatif untuk mencegah kerusakan tulang akibat osteoporosis. Kelemahan utama dari bahan implant ortopedik berbasis hydroksiapatit sinter adalah bahan dalam bentuk solid dimana dalam aplikasi pembedahan, sulit untuk mengisi rongga tulang dengan ukuran tertentu. Alternatif yang nyaman untuk bahan pengisi tulang suspensi adalah dengan menggunakan bahan Injectable bone substitute. Dalam studi ini dipelajari komposisi material Injectable Bone substitute dengan matrik berupa polimer CMC-gelatin dan HA/TCP sebagai filler. Dilakukan variasi rasio Hidroksiapatit (HA) / tri-calcium phosphate (TCP) (70:30; 50:50; 40:60) untuk mempelajari pengaruhnya terhadap sifat-sifat fisik dan mekanik campuran. Hasil uji FTIR menunjukkan gugus fungsi fosfat $\left(\mathrm{PO}_{4}{ }^{3-}\right)$ gugus fungsi karboksil dan gugus fungsi NH2 yang merujuk kepada bahan penyusunnya. Peningkatan porositas karena perubahan morfologi dikonfirmasi oleh gambar mikroskop polaritas. Hasil uji tekan menunjukkan berkurangnya nilai kuat tekan dengan bertambahnya konsentrasi TCP dalam campuran. Semua kelompok uji menunjukkan kemiripan struktural dengan tulang cancellous dalam sifat porositas dan kekuatan mekanik.
\end{abstract}




\section{PENDAHULUAN}

Seiring dengan bertambahnya jumlah populasi penduduk, kasus-kasus patah tulang akibat osteoporosis makin banyak terjadi, dimana osteoporosis menyebabkan massa tulang berkurang sehingga tulang menjadi rapuh [1].

Pada awalnya perbaikan tulang sering dilakukan dengan melakukan penggantian tulang dengan beberapa jenis bone graft (pengganti tulang) diantaranya autograft yang merupakan pengganti tulang yang berasal dari bagian tulang lain pasien yang menderita kerusakan tulang [2] [3]. Autograft masih merupakan standard terbaik untuk penggantian tulang disebabkan sifat osteogenik, osteokonduktif, dan osteoinduktifnya [4][5][6][7]. Kemudian terdapat jenis allograft yaitu tulang yang berasal dari proses pembekuan tulang orang lain atau donor atau spesies yang sama namun berbeda genetik, yang terakhir yaitu xenograft yang berasal dari tulang hewan. Ketiga jenis bone graft memiliki kekurangan yang justru dapat menimbulkan dampak lain karena harus kehilangan tulang bagian lain dan juga jika menggunakan pengganti tulang orang lain atau tulang hewan ketidakcocokkan tulang akan sangat sulit dihindari sehingga dalam kemajuan material alat kesehatan dibuat alternatif bone graft dari biomaterial.

Hidroksiapatit merupakan bahan biokeramik dengan gugus senyawa $\mathrm{Ca}_{10}\left(\mathrm{PO}_{4}\right)_{6}(\mathrm{OH})_{2}$. Gugus senyawa tersebut menyerupai gugus senyawa pada tulang dan gigi manusia [8], karena itu, HA dikenal sebagai material yang biokompatibel [9] dan tidak menimbulkan respon inflamasi, namun nilai resorpsinya rendah [10][11]. $\beta$-TCP sebagian besar digunakan bersamaan dengan HA [8]. Keuntungan utama menggunakan keramik bifasik (campuran HA dan $\beta$ TCP) berkaitan dengan resorpsi keduanya. Diketahui, resorpsi $\beta$-TCP lebih cepat daripada resorpsi HA[12][13]. tetapi sifat mekanik HA sedikit lebih baik daripada $\beta$-TCP. Dengan demikian, hubungan $\beta$ TCP dan HA memungkinkan tingkat pertumbuhan tulang yang lebih cepat dan lebih tinggi daripada menggunakan HA saja sambil menawarkan sifat mekanik yang lebih baik daripada $\beta$-TCP saja.

Beberapa material komposit yang mengandung HA dan kolagen juga telah diteliti, dan kombinasinya meningkatkan diferensiasi osteoblas dan mempercepat osteogenesis [14][15]. Sifat elastis kolagen memungkinkan peningkatan ketangguhan patah hidroksiapatit yang buruk. Namun, efektivitas bahan komposit ini harus divalidasi oleh studi klinis lebih lanjut [8].

Dalam beberapa tahun terakhir, beberapa pengganti tulang suntik (IBS) berbasis kalsium fosfat, dikombinasikan dengan berbagai polimer berbasis alam, seperti selulosa dan turunannya, asam hialuronat dan polimer lainnya, telah dipasarkan sebagai perangkat medis [7].
Bahan yang ideal untuk menggantikan jaringan tulang harus memenuhi spesifikasi yang tepat, seperti menjadi biokompatibel, bioresorbable, osteokonduktif, osteoinduktif, secara struktural mirip dengan tulang, berpori, tahan mekanis, mudah digunakan, aman, dan hemat biaya [16]. Pada penelitian ini, IBS dibuat dengan mendispersikan serbuk HA/TCP kedalam larutan polimer CMC-gelatin dan bahan pendukung lainnya kemudian dilakukan pengujian dan pembandingan sifat fisik sampel dengan sifat fisik tulang manusia.

\section{BAHAN DAN METODE}

Biphasic Calcium Phosphate (BCP) dibuat dengan komposisi HA dan TCP. Pencampuran HA (HA sintetik, produk PTM-BPPT) dan TCP (Sigma Aldrich) dengan perbandingan HA/TCP sebesar 70:30 (sampel A), 50:50 (sampel B), dan 40:60 (sampel C) dilakukan menggunakan alcohol sebagai media pencampuran. Serbuk HA dan TCP dicampur selama 30 menit dengan menggunakan magnetic stirrer didalam larutan alkohol (aseton). Setelah itu campuran disinter dalam oven hingga suhu $80{ }^{\circ} \mathrm{C}$ selama 17 jam hingga diperoleh serbuk campuran kering.

Fasa likuid dibuat dengan mencampur Larutan gelatin (lokal, Sumber Berlian Kimia, food grade) $10 \%$ (w/w) ditambahkan dengan larutan CMC (sigma Aldrich) $2 \%(\mathrm{w} / \mathrm{w})$ dengan perbandingan gelatin: CMC (4:1). Setelah itu larutan gelatin-CMC diaduk menggunakan magnetic stirrer dengan kecepatan 600 rpm selama 10 menit. Setelah larutan gelatin-CMC homogen, dilakukan penambahan serbuk HA/TCP sesuai dengan variasi komposisi yang telah ditentukan (Sampel A, B dan C) kemudian diaduk hingga homogen dan terbentuk suspensi yang berwarna putih. Suspensi yang telah terbentuk dimasukkan kedalam alat syringe untuk dicetak kedalam pencetak komposit HA/TCP-Gelatin-CMC

Sebelum diuji sampel ditimbang menggunakan neraca analitik. Pengujian sifat fisik meliputi Uji degradasi, uji swelling, uji porositas,uji densitas, uji kekuatan kompresi, pengukuran pori dan dilakukan karakteristik menggunakan FTIR.

\section{A. Uji Degradasi}

Uji degradasi dilakukan untuk mengobservasi kehilangan berat sampel sebelum dan sesudah dilakukan perendaman di dalam larutan fisiologis Ring$e r$, pengujian dilakukan selama 7 hari. Berat awal dan akhir sampel diukur dengan menggunakan alat ukur berat digital yang memiliki ketelitian $10^{-4}$. Nilai degradasi merupakan presentase selisih antara berat awal dan berat akhir sampel per berat awalnya.

\section{B. Uji Swelling}

Uji swelling dilakukan untuk mengobservasi kemampuan sampel untuk mengembang dan sebagai wadah tempat sel-sel tulang baru. Berat awal dan akhir 
sampel diukur dengan menggunakan alat ukur berat digital yang memiliki ketelitian $10^{-4}$. Nilai swelling merupakan presentase selisih antara berat basah sampel setelah direndam dan berat awal sampel per berat awalnya.

\section{Uji Porositas}

Uji porositas dilakukan untuk mengobservasi interkoneksi antar pori pada sampel IBS apakah sesuai dengan ukuran porositas tulang manusia. Besarnya porositas merupakan presentase perbandingan antara selisih berat basah dan berat awal dengan selisih antara berat basah dan berat sampel didalam air.

\section{Uji Densitas}

Uji densitas dilakukan untuk mengobservasi kerapatan sampel IBS apakah sesuai dengan kerapatan tulang manusia. Besar densitas dihitung menggunakan formula :

$$
\begin{aligned}
& \mathrm{P}=\mathrm{A} /(\mathrm{A}-\mathrm{B}) *(\text { po-d })+\mathrm{d} \\
& \mathrm{P}=\text { densitas sampel } \\
& \mathrm{A}=\text { berat sampel diudara } \\
& \mathrm{B}=\text { berat sampel dalam air } \\
& \mathrm{Po}=\text { densitas cairan } \\
& \mathrm{D}=\text { densitas udara }
\end{aligned}
$$

\section{E. Uji Tekan}

Uji tekan dilakukan untuk mengamati kemampuan sampel. Kemampuan sampel harus sesuai dengan kekuatan tulang manusia agar dapat digunakan sebagai pengisi tulang manusia. Uji tekan menggunakan alat UTM (shimadzu AGX series) dengan probe silinder dengan kecepatan deformasi $1 \mathrm{~mm} / \mathrm{min}$ dan gaya tekan maksimal $240000 \mathrm{~N}$.

\section{F. Uji FTIR}

Karakterisasi dengan menggunakan FTIR dilakukan untuk mengetahui gugus fungsi yang terkandung di dalam sampel. Pengukuran dilakukan menggunakan spektrofotometer FTIR (Perkin-elmer spectrum 100).

\section{G. Pengukuran Besar Pori}

Pengukuran besar pori dilakukan untuk mengamati besar pori sampel. Pengukuran dilakukan menggunakan mikroskop polarisasi. Sampel diamati dengan perbesaran sepuluh kali.

\section{HASIL DAN PEMBAHASAN}

Pengujian densitas komposit BCP-gelatinCMC menunjukkan bahwa makin tinggi kandungan TCP dibanding HA, densitas komposit makin berkurang, sebagaimana ditunjukkan pada Tabel 1.
Tabel 1. Hasil uji densitas dan porositas pada komposisi sampel.

\begin{tabular}{ccc} 
Sampel & Densitas & Porositas \\
\hline A & 1,72 & $53,5 \%$ \\
B & 1,68 & $78,88 \%$ \\
C & 1,59 & $88,69 \%$ \\
\hline
\end{tabular}

Pada semua variasi komposisi HA:TCP, densitas yang dihasilkan ada dibawah nilai densitas tulang padat $\left(3,1-3,2 \mathrm{~g} / \mathrm{cm}^{3}\right)$ dan mendekati densitas tulang cancellous. Kepadatan nyata dari tulang cancellous manusia biasanya berkisar 0,05 hingga $1,1 \mathrm{~g} / \mathrm{cm}$. Berkurangnya densitas disebabkan karena adanya perbedaan berat jenis HA dengan TCP. Berkurangnya densitas diikuti juga oleh bertambahnya porositas. Penelitian ini menunjukkan bahwa dalam sistem BCP, porositas dapat diatur dengan rasio HA/TCP untuk mendapatkan porositas yang diinginkan. Porositas yang dihasilkan pada sampel A yaitu 53,5\%, sampel B $78,88 \%$ dan sampel C 88,69\% memiliki kemiripan dengan porositas tulang cancellous yaitu $30-90 \%$. Lebih jauh, porositas adalah faktor penting yang mempengaruhi kecepatan degradabilitas. Bahan dengan porositas tinggi memiliki kecepatan penguraian yang tinggi, dan material dengan porositas rendah memiliki kemampuan penguraian yang lebih rendah. Dengan porositas yang semakin meningkat maka sel jaringan berada disekitarnya mudah masuk ke dalam dan berproliferasi (pertambahan sel dengan cepat). Hal ini akan meningkatkan sifat osteokonduktif (kemampuan untuk memandu pertumbuhan sel tulang) dari matriks sebagai scaffold. Matriks yang mengandung gelatin sebagai protein tulang akan dapat berfungsi membantu berkembangnya sel jaringan untuk membentuk challus, yang selanjutnya bereaksi dengan kalsium dengan bantuan osteoblas membentuk tulang baru. [17]

\section{Uji Swelling Ability Dan Degradasi}

Pengujian sifat degradasi dari sampel dalam lingkungan basah, maka dilakukan perendaman dari sampel dalam larutan SBF. Hasil uji dapat dilihat pada Tabel 2 berdasarkan data dalam tabel tersebut menunjukkan bahwa dengan terjadinya meningkatnya konsentrasi TCP, menyebabkan angka swelling bertambah dam degradasi meningkat. Penurunan densitas yang terjadi akibat peningkatan konsentrasi TCP telah meningkatkan porositas campuran, yang menyebabkan air/cairan akan semakin mudah untuk berdifusi kedalam sampel sehingga pemekaran (swelling) semakin meningkat, dan sampel mudah untuk terdegradasi. 
Tabel 2. Hasil uji swelling ability dan degradasi.

\begin{tabular}{ccc} 
Sampel & Swelling & Degradasi \\
\hline A & 30,79 & $7,33 \%$ \\
B & 40,85 & $8,1 \%$ \\
C & 55,37 & $8,25 \%$
\end{tabular}

Dalam uji degradasi ini hanya menginvestigasi kecenderungan terjadinya degradasi akibat perbedaan rasio HA/TCP. Degradabilitas ideal sebuah material bone graft yaitu dapat melebur dalam waktu 5-7 minggu[18]. Hal tersebut berhubungan dengan pembentukan tulang baru. Pembentukan tulang baru berlangsung selama 4-8 minggu sehingga pada waktu tersebut diharapkan material bone graft dapat terurai seiring dengan adanya proses pembentukan alami tulang.

\section{Uji Tekan}

Uji tekan merupakan uji untuk mengetahui apakah komposit memenuhi persyaratan bahan sebagai pengisi tulang. Menurut ketentuan persyaratan bahan dapat digunakan sebagai pengganti tulang jika memiliki kuat tekan antara 2-12 Mpa pada tulang canceollus dan untuk tulang cortical memiliki kuat tekan antara 30-160 Mpa [19]

Tabel 3. Hasil uji tekan.

\begin{tabular}{|c|c|c|c|c|c|}
\hline Komposisi & Sampel & $\begin{array}{l}\text { Max.Stress } \\
(\mathrm{MPa})\end{array}$ & $\begin{array}{l}\text { Max.Force } \\
\text { (N) }\end{array}$ & $\begin{array}{l}\text { Max.Stroke } \\
(\mathrm{mm})\end{array}$ & $\begin{array}{c}\text { Rata-rata } \\
\text { Max. } \\
\text { Stress } \\
(\mathrm{MPa})\end{array}$ \\
\hline \multirow{3}{*}{ A } & 1 & 12,35 & 730,52 & 1,57 & \multirow{3}{*}{13,53} \\
\hline & 2 & 14,90 & 848,65 & 1,65 & \\
\hline & 3 & 13,34 & 757,14 & 1,52 & \\
\hline \multirow{3}{*}{ B } & 1 & 9,77 & 638,21 & 1,71 & \multirow{3}{*}{10,14} \\
\hline & 2 & 10,38 & 598,99 & 1,67 & \\
\hline & 3 & 10,27 & 686,84 & 1,77 & \\
\hline \multirow{3}{*}{$\mathrm{C}$} & 1 & 3,31 & 234,09 & 1,46 & \multirow{3}{*}{3,76} \\
\hline & 2 & 4,32 & 293,85 & 2,06 & \\
\hline & 3 & 3,66 & 259,56 & 1,46 & \\
\hline
\end{tabular}

Tabel 3 menunjukkan adanya penurunan kekuatan yang disebabkan meningkatnya konsentrasi TCP dalam campuran. Pada sampel A menghasilkan kekuatan sebesar 13,53 Mpa, sampel B menghasilkan 10,14 Mpa dan sampel C menghasilkan 3,76 Mpa. Hasil tersebut menunjukkan bahwa komposit BCPgelatin-CMC untuk semua komposisi berada pada rentang nilai kuat tekan tulang cancellous (2-12 Mpa.)

\section{Karakterisasi FTIR}

Komposit HA-TCP-gelatin-CMC dikarakterisasi dengan menggunakan FTIR untuk mengetahui gugus fungsi dari bahan-bahan pembentuknya terdapat di dalamnya. Spektrum FTIR komposit HA-TCPgelatin-CMC untuk sampel A yang diambil sebagai representasi dari metode pencampuran sistem komposit HA-TCP-gelatin-CMC dapat dilihat pada Gambar 2 .

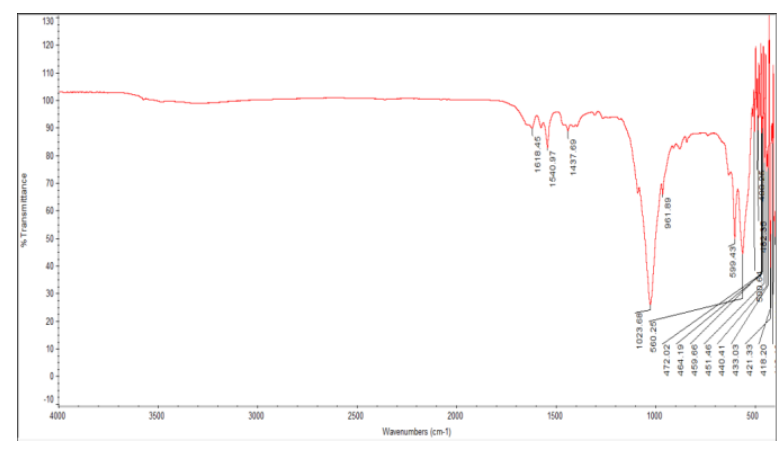

Gambar 1. Hasil karakterisasi sampel dengan rasio HA/TCP 50:50.

Pada spektrum FTIR diatas bilangan gelombang 1023,68 $\mathrm{cm}^{-1} 560,25 \mathrm{~cm}^{-1}$ merupakan daerah serapan dari gugus fungsi fosfat (PO43-) yang berasal dari senyawa kalsium fosfat yaitu HA dan TCP. Pada bilangan gelombang $1437.69 \mathrm{~cm}^{-1}$ merupakan daerah serapan dari gugus fungsi karboksil (COO-) yang berasal dari prolin gelatin dan dapat berasal dari CMC karena kedua senyawa tersebut memiliki gugus fungsi karboksil. Dan terdapat pula gugus $\mathrm{NH}_{2}$ pada serapan $1540,97 \mathrm{~cm}^{-1}$ yang berasal dari senyawa gelatin [17]. Hal ini menunjukkan bahwa metode pencampuran pada pembuatan komposit HA-TCP-gelatin-CMC tidak menimbulkan persenyawaan baru dengan tidak ditemukannya indikasi gugus fungsi dari persenyawaan lain.

\section{Pengukuran Besar Pori}

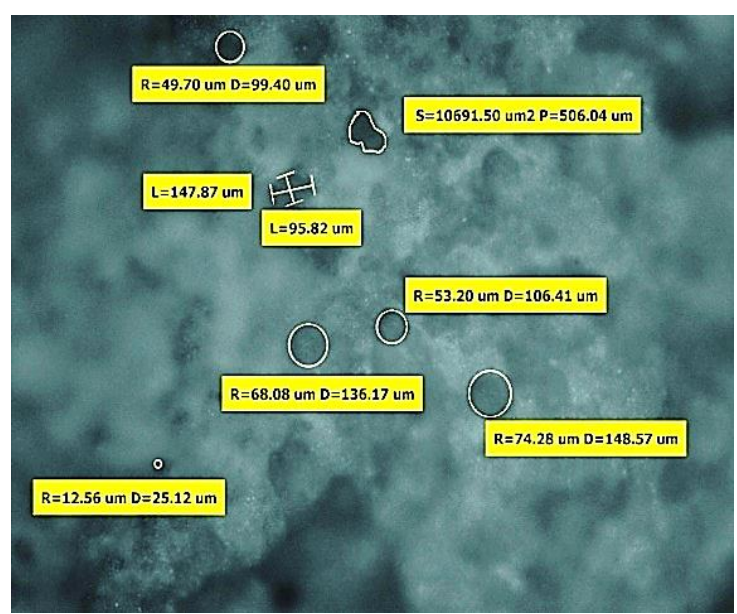

Gambar 2. Hasil pengamatan Sampel A dengan mikroskop polarisasi dengan pembesaran 10x. 


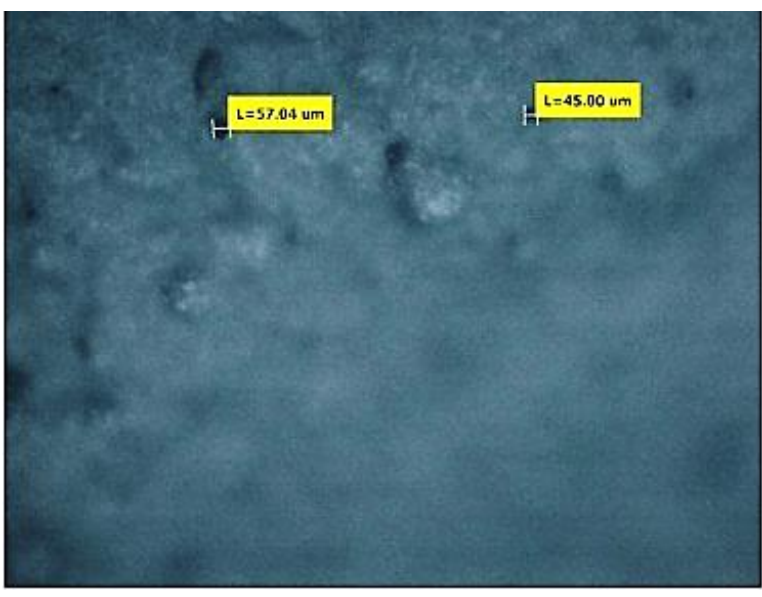

Gambar 3. Hasil pengamatan Sampel B dengan mikroskop polarisasi dengan pembesaran 10x.

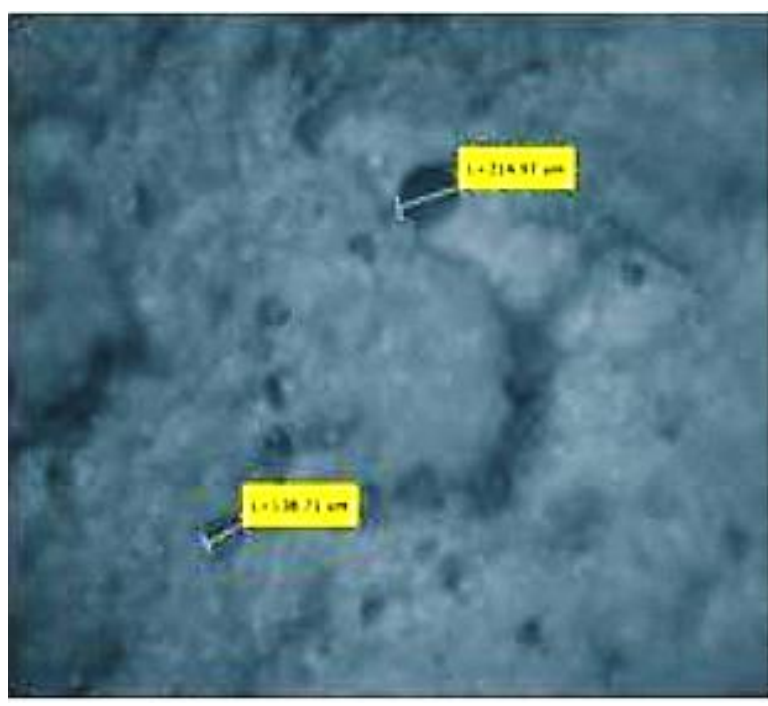

Gambar 4. Hasil pengamatan Sampel C dengan mikroskop polarisasi dengan pembesaran $10 \mathrm{x}$.

Berdasarkan hasil pengamatan menggunakan mikroskop polarisasi besar pori yang terukur, sampel A memiliki ukuran pori pada kisaran 99-500,04 mikron, sampel B 45-605 mikron dan sampel C 65769 mikron dengan penyebaran ukuran pori yang bervariasi pada setiap permukaan. Kehadiran fitur makrostruktural seperti makropori, kanal atau void antar partikel meningkatkan sifat osteoinduksi bahan. [20]. Ukuran pori ideal untuk biokeramik harus sama dengan ukuran tulang spons (cancellous bone). Mikroporositas (ukuran pori < 10 mikron) memungkinkan sirkulasi cairan tubuh sedangkan makroporositas (ukuran pori > 50 mikron) memberikan perancah (ukuran pori 100-200 mikron dan porositas 60-65\%) untuk kolonisasi sel-tulang [21]. Ukuran pori berdiameter 565 mikron dilaporkan sebagai ukuran makropori ideal untuk pertumbuhan tulang dibandingkan dengan ukuran yang lebih kecil (300 mikron) [22]. Dengan demikian, secara keseluruhan ukuran pori yang dihasilkan untuk setiap komposisi memiliki ukuran pori yang ideal sebagai bahan pengganti tulang.

\section{KESIMPULAN}

Variasi HA/TCP berpengaruh pada densitas, porositas,kuat tekan, pemekaran, dan persentase hilang sampel dengan larutan SBF pada komposit HA/TCP-gelatin-CMC. Secara garis besar kenaikan kosentrasi TCP dalam rasio HA/TCP akan menurunkan nilai densitas dan meningkatkan persentase porositas yang diikuti dengan meningkat pemekaran (swelling) sehingga degaradasi meningkat dan menurunkan nilai kuat tekan pada komposit HA/TCP-gelatin-CMC. Investigasi pada makrostruktural bahan menunjukkan bahan IBS pada berbagai rasio HA/TCP memenuhi sifat-sifat osteoinduksi yang diinginkan, ditinjau dari nilai keporian dan ukuran pori (dalam rentang yang mirip dengan tulang cancelous). Namun untuk membutikan bahwa formulasi ini tepat untuk bahan IBS, perlu validasi lebih lanjut terutama untuk mengetahui laju degradasi bahan dalam kurun waktu yang sesuai (4-5 minggu) dan analisa rheologi bahan yang berkaitan dengan kemudahan dalam injeksi dan pengerasan in-situ. Uji pra klinis diperlukan untuk mempelajari hasil formulasi untuk mengetahui pengaruh bahan terhadap proliferasi sel untuk mempercepat perbaikan tulang

\section{UCAPAN TERIMAKASIH}

Studi ini dilakukan atas dukungan dana dan fasilitas dari Pusat Teknologi Material, Badan Pengkajian dan Penerapan Teknologi

\section{DAFTAR PUSTAKA}

[1] Bohner M, Gasser B, Baroud G, Heini P. 2003. "Theoretical and experimental model to describe the injection of a polymethylmethacrylate cement into a porous structure". Biomaterials;24: 2721-2730.

[2] Samartzis D, Shen FH, Goldberg EJ,An HS. 2005. "Is autograft the gold standard in achieving radiographic fusion in one-level anterior cervical discectmy and fusion with rigid anterior plate fixation?" Spine (Phila Pa 1976);30:1756-61.

[3] Greenwald AS,Boden SD,Goldberg VM, et al. 2001."Bone-graft substitutes:facts,fictions, and applications". J Bone Joint Surg Am;83-A(Suppl. $2(\operatorname{Pt} 2)): 98-103$.

[4] Wimmer C, Krismer M, Gluch H, Ogon M, Stockl B. 1999. "Autogenic versus allogenic bone grafts in anterior lumbar interbody fusion". Clin Orthop;360:122-126 
[5] Merkx MAW, Maltha JC, Freihofer HP, Kuijpers-Jagtman AM. 1999. "Incorporation of three types of bone block implants in the facial skeleton". Biomaterials;20:639-645

[6] Sarkar MR, Wachter N, Patka P, Kinzl L. 2000. "First histological observations on the incorporation of a novel calcium phosphate bone substitute material in human cancellous bone". J Biomed Mater Res;58:329-334

[7] Larsson S, Hannink G. 2011."Injectable Bone substitute : current product, their characteristics and indications, and new development". Injury;42 suppl 2;S30-4

[8] Campana V, Milano G, Pagano E, Barba M, Cicione C, Salonna G, Lattanzi W, Logroscino G. 2014 Oct. " Bone substitutes in orthopaedic surgery: from basic science to clinical practice ". J Mater Sci Mater Med.; 25(10):2445-61

[9] Ghosh SK, Nandi SK, Kundu B, Datta S, De DK, Roy SK, Basu D J. 2008 Jul ." In vivo response of porous hydroxyapatite and beta-tricalcium phosphate prepared by aqueous solution combustion method and comparison with bioglass scaffolds ".Biomed Mater Res B Appl Biomater.; 86(1):217-27

[10] Spivak JM, Hasharoni .2001 Oct." A Use of hydroxyapatite in spine surgery".Eur Spine J.; 10 Suppl 2:S197-204

[11] Xie J, Baumann MJ, Mc Cabe LR. 2004 Oct. "Osteoblasts respond to hydroxyapatite surfaces with immediate changes in gene expression". J Biomed Mater Res A. 1; 71(1):108-17

[12] Saikia KC, Bhattacharya TD, Bhuyan SK, Talukdar DJ, Saikia SP, Jitesh P .2008 Apr."Calcium phosphate ceramics as bone graft substitutes in filling bone tumor defects".Indian J Orthop.; 42(2):169-72

[13] Lee KS, Chang JS, Kim JH, et al. 2009."The role of osteoclast in resorption of hydroxyapatite and $\beta$-tricalcium phosphate coating layer". Key Eng Mater ; 396-398: 81-84

[14] Sarikaya Burcu, Aydin HM. 2015. "Collagen/Beta-Tricalcium Phosphate Based Synthetic Bone Grafts via Dehydrothermal Processing". BioMed Research International Volume. Article ID 576532

[15] Ko-Ning Ho, Eisner Salamanca, Kuo-Chi Chang et.al. 2016." A Novel HA/ $\beta$-TCP-Collagen Composite Enhanced New Bone Formation for Dental Extraction Socket Preservation in Beagle Dogs". Materials, 9, 191; doi:10.3390/ma9030191

[16] Faour O, Dimitriou R, Cousins CA, Giannoudis PV. 2011 Sep. "The use of bone graft substitutes in large cancellous voids: any specific needs?". Injury 42 Suppl 2:S87-90

[17] Aniek S.B., Muhamad Z., Ferdiansyah., dan Fathia R. 2010. "Efektivitas Matriks Komposit Bovine Hydroxyapatite - Gelatin Sebagai Sistem Penghantaran Gentamisin Dan Re- generasi Tulang Pada Bone Defect", Tesis, Program Pascasarjana Ilmu Kedokteran, Universitas Airlangga, Surabaya.

[18] Moore, William R., Graves, Stephen E., Bain, Gregory I. 2001. Synthetic Bone Graft Substitutes, ANZ J. Surg., 71, 354-361

[19] An YH. 2000."Mechanical properties of bone". In: An YH, Draughn RA, editors. Mechanical testing of bone and the bone-implant interface. Boca Raton: CRC Press; p. 41

[20] Daculsi G, LeGeros RZ, Heughebaert M, Barbieux I. 1990."Formation of carbonate- apatite crystals after implantation of calcium phosphate ceramics". Calcif Tissue Int;46:20-7

[21] Gauthier O, Bouler JM, Weiss P, et al. 1999. "Kinetic study of bone ingrowth and ceramic resorption associated with the implantation of different injectable calciumphosphate bone substitutes". J Biomed Mater Res;47:28-35

[22] H. Yuan, H. Fernandes, P. Habibovic, J. D. Boer, A. M. C. Barradas, an A.D. Ruiter.2010. "Osteoinductive ceramics as a synthetic alternative to autologous bone grafting," Image (Rochester, N.Y.), vol. 107 , no. $31: 10-1$ 